\title{
Changing climate-changing pathogens: Toxoplasma gondii in North-Western Europe
}

\author{
Bastiaan G. Meerburg • Aize Kijlstra
}

Received: 28 March 2009/Accepted: 17 April 2009/Published online: 6 May 2009

(C) The Author(s) 2009. This article is published with open access at Springerlink.com

\begin{abstract}
In this review, we describe the effects of global climate change for one specific pathogen: the parasite Toxoplasma gondii. It is postulated that an increase of $T$. gondii prevalence in humans can occur in some regions of North-Western Europe as a result of changing environmental conditions. Such a change can be predicted by using Global Climate Change models. We have elaborated such a prediction for one scenario (SRES A1) by using one specific model (CCSR/NRIES) as an example. Next to environmental factors, also anthropogenic factors may contribute to increased prevalence of $T$. gondii in this region. In order to counter the potential severe consequences of a potential increase resulting from the combination of climatic and anthropogenic factors, there is an urgent need for the development of a human vaccine. Until a vaccine that offers complete protection is developed, the emphasis should be on treatment optimization and prevention.
\end{abstract}

B. G. Meerburg $(\square)$

Wageningen University and Research Centre,

Plant Research International,

P.O. Box 616, 6700 AP Wageningen, The Netherlands

e-mail: Bastiaan.Meerburg@wur.nl

\author{
A. Kijlstra \\ Wageningen University and Research Centre, \\ Animal Sciences Group, \\ P.O. Box 65, 8200 AB Lelystad, The Netherlands \\ e-mail: Aize.Kijlstra@wur.nl
}

\author{
A. Kijlstra \\ Department of Ophthalmology, Faculty of Medicine, \\ University of Maastricht, \\ Maastricht, The Netherlands
}

\section{Overview}

Toxoplasma gondii is a protozoan parasite of the Coccidian family which is considered as the most prevalent parasitic zoonotic disease in the world (Tenter et al. 2000). The parasite has a complex life cycle, in which cats function as definitive hosts. During one stage of $T$. gondii's life cycle, felines transmit the parasite to the environment through shedding millions of $T$. gondii oocysts. After sporulation and upon intake by intermediate hosts, such as birds or rodents, other species can get infected with $T$. gondii (Dubey et al. 1995; Kijlstra et al. 2008). Humans can contract the parasite through consumption of undercooked and infected meat from food animals (Cook et al. 2000; Dubey 2008), or by water or food products that are contaminated with oocysts (Dubey and Jones 2008).

Congenital transmission does occur and may lead to severe problems in unborn children and babies, including abortion, hydrocephalus, neurological disorders, and retinochoroiditis (Wallon et al. 2004). Reactivation of undiagnosed congenital toxoplasmosis can lead to ocular toxoplasmosis later in life, leading in many cases to blindness even with treatment (Bosch-Driessen et al. 2002; Wallon et al. 2004). In the USA, it is estimated as the third cause of death by food-borne pathogens (Mead et al. 1999), and also in Europe it can be considered as one of the main pathogens (Havelaar et al. 2007). Unfortunately, detection of the parasite in the human body is difficult (Montoya and Liesenfeld 2004).

Here, we postulate that global warming will cause an increase of $T$. gondii seroprevalence in humans in some regions of in North-Western Europe. This increase due to environmental factors will be coincided with anthropogenic factors such as urbanization and re-emergence of the parasite due to changes in livestock systems. 


\section{Global warming in North-Western Europe}

Global warming resulting from greenhouse emissions is projected to lead to a changing climate in North-Western Europe. Changes in temperature, rainfall, and atmospheric $\mathrm{CO}_{2}$ concentrations will affect multiple biophysical processes, including the life cycle of pathogens. Moreover, climate change influences the habitat of animals; as a consequence, range shifts will occur (Parmesan and Yohe 2003). Species that are incapable of adapting to these changes will become extinct (Thomas et al. 2004). The combination of changing biotic and abiotic factors will have a significant effect on existing pathogen cycles.

The evaluation of climate change is based on simulations with global climate models (GCM) for the four IPCC emissions scenario families (Houghton et al. 2001), see also Table 1. Climate researchers have deduced a number of climatic scenarios from these scenario families, each with their own characteristics. As a result, each model has its specific outcome and predictions. As an example, the projected changes in annual precipitation are presented for North-Western Europe as calculated by the Hadley Centre for a B2 climate change scenario in 2080 in Fig. 1.

Generally, however, these scenarios indicate that annual temperatures over Europe warm at a rate of between 0.1 and $0.4^{\circ} \mathrm{C}$ decade ${ }^{-1}$. In Northern Europe (which includes the United Kingdom, Northern Germany, Denmark, Belgium, Luxemburg, and the Netherlands), the projected temperatures are highest in winter, while annual precipitation is likely to increase between $+1 \%$ and $+2 \%$ decade $^{-1}$ (Ruosteenoja et al. 2003). In the United Kingdom, a rise of mean temperatures of $2-3.5^{\circ} \mathrm{C}$ in 2080 is expected, depending on the exact location and the scenario that is used for calculation purposes. The greatest temperature increase will be in the southern and eastern parts of the country. More winter precipitation and less summer precipitation are expected (Anonymous 2002). On the other side of the North Sea, for example in the Netherlands, the temperatures will also increase (Van den Hurk et al. 2006). Because of the main wind directions (south and west), mean day temperatures will increase in the autumn and winter. In 2100 , temperatures may have risen by $1.1-$ $6.4^{\circ} \mathrm{C}$ compared to the mean day temperature of 1990 , with the maximum likelihood of $1.8-4^{\circ} \mathrm{C}$ (Van den Hurk et al. 2006). Temperature extremes will increase; although there will be less cold days, the coldest winter days will become colder. On the other hand, the warmest summer days will be hotter. Similarly to the United Kingdom, winter precipitation will increase while the summer precipitation will slightly reduce (Van den Hurk et al. 2006).

Generally, three main trends can be distinguished in the North-Western European region (Van den Hurk et al. 2006). These are: (1) an increase in total precipitation (Fig. 2); (2) an increase in mean temperature (Fig. 3); and (3) an increase in weather extremes. It can be expected that these factors will influence the prevalence of toxoplasmosis in this region. By combining the information from Figs. 2 and 3 (precipitation and temperature), we have made a map of those regions where more $T$. gondii presence is expected in the future. This map is displayed in Fig. 4. Although this map is highly speculative as it is based upon the projections of only one scenario (A1) and of only one model (CCSR/ NIES), it demonstrates that by combining different climatic information sources it will become possible to predict changes in $T$. gondii prevalence.

\section{Global warming and $T$. gondii}

Each environmental change, whether occurring as a natural phenomenon or through human intervention, changes the ecological balance and context within which disease hosts or vectors and parasites breed, develop, and transmit disease (Patz et al. 2000). When focusing specifically on T. gondii, three different effects can be identified: (1) pathogen survival will be affected by environmental changes; (2) because of increased precipitation, sporulated oocysts are more easily spread throughout the environment; and (3) climate change will influence the ecology of (transport) hosts.

First, environmental conditions are important for oocyst survival. Worldwide, prevalence of Toxoplasma is high in

Table 1 Main climate change scenario families as defined in the SRES (Special Report on Emissions Scenarios) report by the IPCC

\section{Scenario Description}

A1 Rapid economic growth, global population 9 billion in 2050 then a gradual decline, quick spread of new technologies, convergent world in terms of income and life between regions. Extensive social and cultural interaction.

A2 A world of independently operating, self-reliant nations, continuous growth of the global population, regionally oriented economic development, slower and more fragmented spread of technological changes.

B1 Rapid economic growth (similar to A1), but more rapid changes to a service and information economy, population growth similar to A1, reduction in material intensity and introduction of more resource efficient or even clean technologies, worldwide emphasis on economic, social and environmental stability. 
Fig. 1 Projected changes in annual precipitation in case of a B2 scenario. Source: HadCM3 model, Hadley Centre, United Kingdom

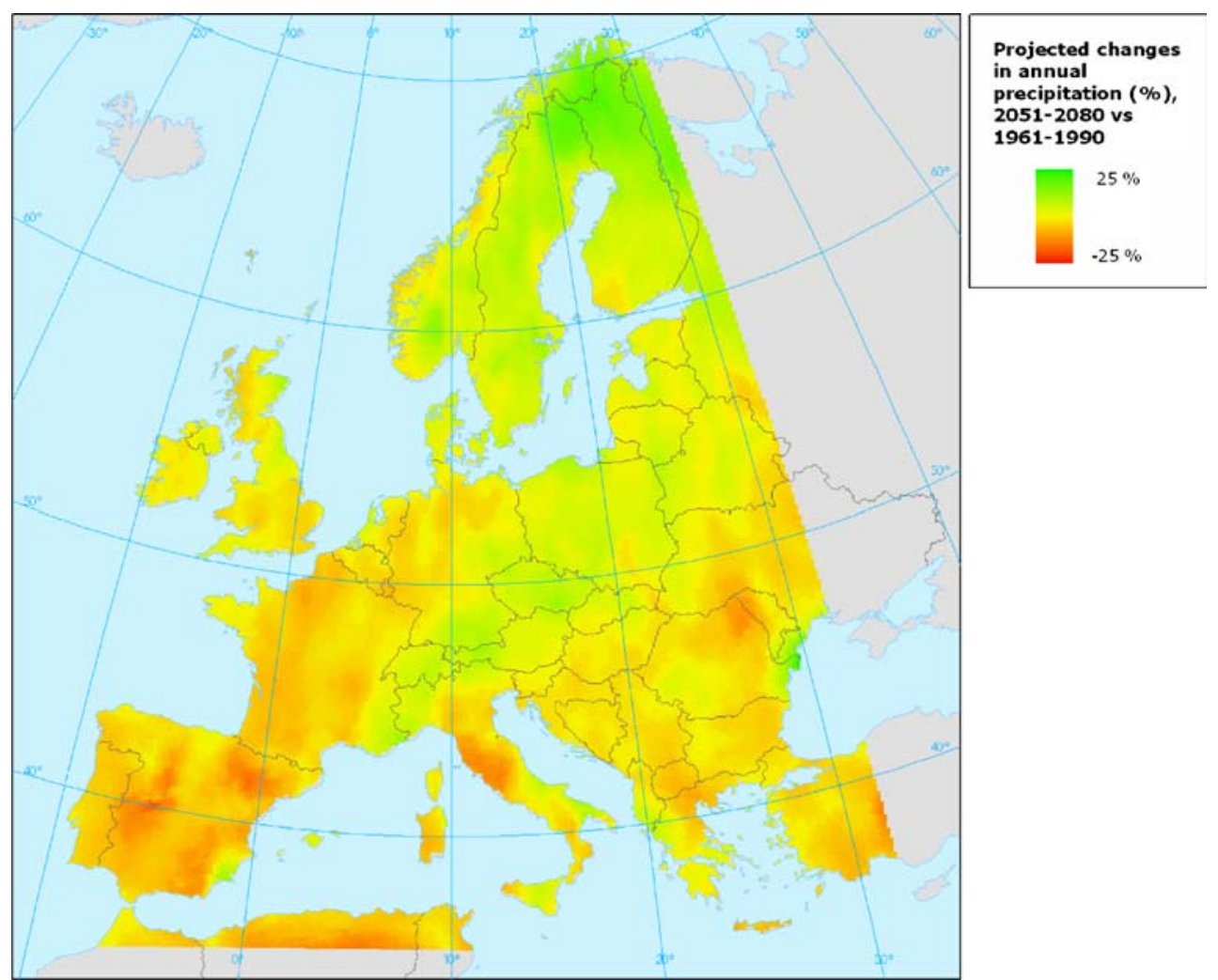

humid tropical areas and low in hot and dry areas. Prevalence of the parasite in arctic areas is also low (Tenter et al. 2000). The environmental resistance of $T$. gondii oocysts may depend on the stage of sporulation (Lindsay et al. 2002). The sporulation process means that parasite oocysts must mature between 1 and 5 days to become infective for other hosts. Sporulated oocysts remain viable in a moist environment for a number of years (Dubey and Beattie 1988), since they can largely resist threats such as heat and cold. Under laboratory conditions, sporulated oocysts survived storage at $4^{\circ} \mathrm{C}$ for up to 54 months and freezing at $-10^{\circ} \mathrm{C}$ for 106 days (Dubey 1998). It has been also demonstrated that sporulated oocysts survived at least 32 days at $35^{\circ} \mathrm{C}$ and 9 days at $40^{\circ} \mathrm{C}$, while exposure at a temperature of $37^{\circ} \mathrm{C}$ during a period of $24 \mathrm{~h}$ was lethal for non-sporulated oocysts (Dubey et al. 1970).

Climate change causes increasing temperatures, drier summers, and wetter winters. Because mean winter temperatures are increasing (except for some short periods of extreme winter weather), sporulated oocyst survival is likely to increase. This increase can have consequences for $T$. gondii prevalence in intermediate and final hosts.

It is known that climatic factors directly influence the risk of infection in cats. In a 10-year study in an urban population of domestic cats in France, it was demonstrated that prevalence of antibodies against $T$. gondii was related to the interaction between temperature and rain (Afonso et al. 2006). The risk of infection increases when the weather was both warm and moist, or moderated and less moist. These authors hypothesized that moist conditions can increase oocyst survival during longer periods of heat (Afonso et al. 2006), a suggestion also mentioned by others (Frenkel et al. 1975). In the USA, the lowest T. gondii antibody prevalences in cats were encountered in the most arid regions of the country (Vollaire et al. 2005).

Sources of human T. gondii infection are oocysts shed in feces of infected felines that may be ingested by humans by consumption of uncooked fruit, berries, or vegetables (Kapperud et al. 1997) or tissue cysts from infected meat animals (Meerburg et al. 2006; Kijlstra and Jongert 2008, 2009). It is therefore plausible that if sporulated oocyst survival increases, also the number of human infections will increase. Tenter (Tenter et al. 2000) has demonstrated that the seroprevalence in women of childbearing age is higher in those countries that have a warmer climate. In France, for example, seroprevalence was $54-58 \%$, compared to only $10-22 \%$ in the United Kingdom and $22-27 \%$ in Denmark (Tenter et al. 2000). However, this difference can partly be attributed to different food habits (e.g., consumption of raw lamb meat). Moreover, in the future, this difference in seroprevalences between Northern and Southern Europe may become smaller or even shift, as climate change will also affect incidence of $T$. gondii in Southern European countries (more arid).

In North-Western Europe, more water will need to be drained from the land and transported elsewhere because of 
Fig. 2 Total precipitation in North-Western Europe as calculated by the CCSR (Center for Climate System Research,

University of Tokyo) and NIES (National Institute for Environmental Studies) model under a SRES A1 scenario. Presented is the total mean precipitation in period from 1970 to 1999 (a), and the projected total mean precipitation from 2010 to 2039 (b) and 2040-2069 (c). Figures obtained from www.ipcc-data.org
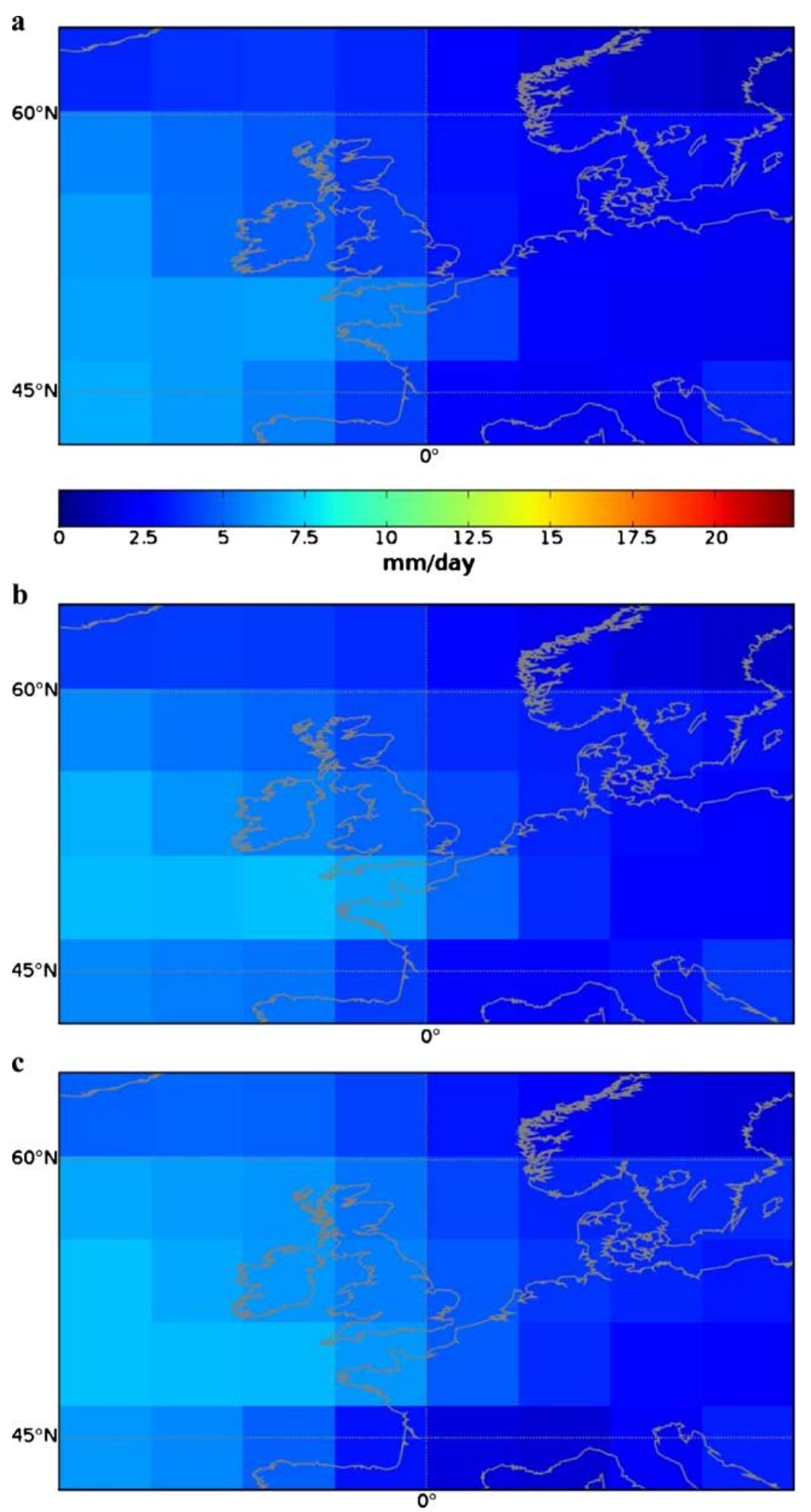

the higher amounts of precipitation and weather extremes. The chance that this water is polluted with sporulated oocysts will increase. Drinking water can be a source of human infection (Benenson et al. 1982; Aramini et al.
1999; Bahia-Oliveira et al. 2003; Sroka et al. 2006). For example, in March 1995, a sudden increase in serologically diagnosed cases of acute toxoplasmosis was observed in the Greater Victoria area of British Columbia, Canada. These 
Fig. 3 Mean temperatures in North-Western Europe as calculated by the CCSR (Center for Climate System Research,

University of Tokyo) and NIES (National Institute for Environmental Studies) model under a SRES A1 scenario. Presented are mean temperatures in period from 1970 to 1999 (a), and the projected mean temperatures from 2010 to 2039 (b) and 2040-2069 (c). Figures obtained from www.ipcc-data.org
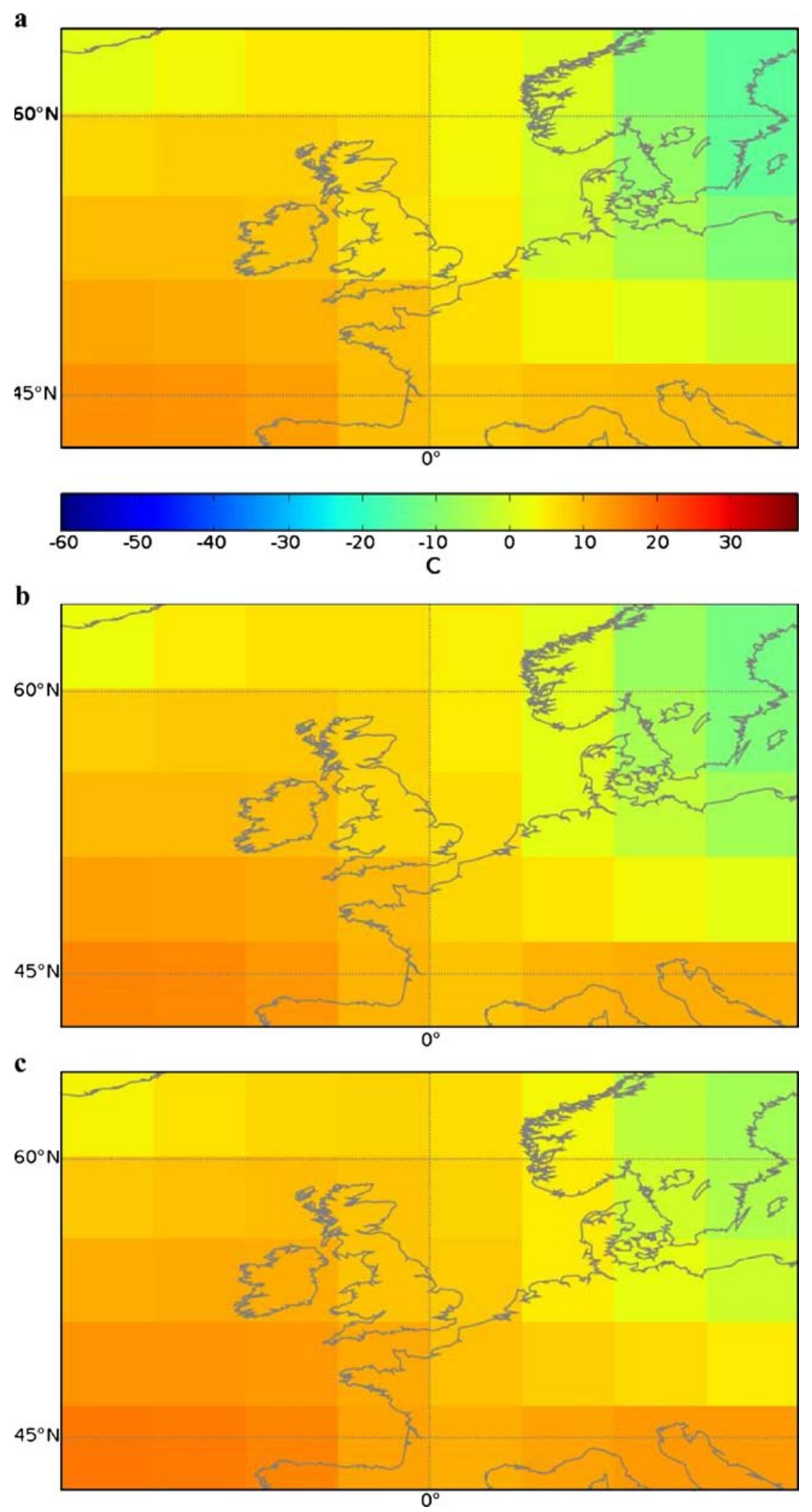

acute cases were linked to residence in the distribution system of one reservoir supplying water to Greater Victoria. The epidemics were preceded by peaks of heavy rainfall and turbidity in the implicated reservoir (Bowie et al.
1997). It was found that domestic and feral cats and cougars shed $T$. gondii oocysts near the water edge, thus causing outbreaks in times of high precipitation (Aramini et al. 1999). Moreover, freshwater runoff from urban 
Fig. 4 Expected increases in $T$. gondii prevalence in NorthWestern Europe towards 2069 based upon the combination of climatic conditions from Figs. 2 and 3. The dotted bright green areas indicate a small increase in $T$. gondii prevalence as a result of climatic change, pink areas a limited increase, and red areas a substantial increase

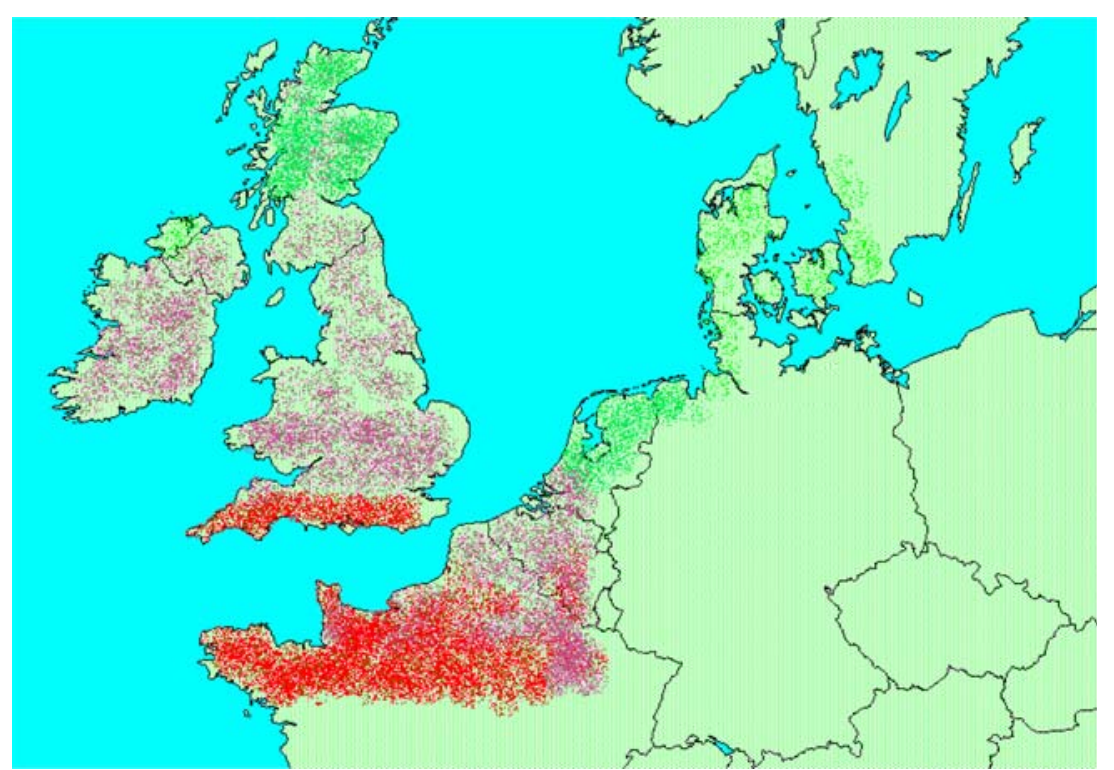

centers may cause extensive infection of wildlife such as is the case along the California coast with southern sea otters (Enhydra lutris nereis) (Miller et al. 2002). Similar problems could occur in North-Western Europe due to changing climatic conditions.

Changes in environmental conditions can also lead to changing ecological patterns of host species. New ecological equilibriums (based on biological principles such as predator-prey relationships) will have to settle themselves for many species. In insect populations, for example, increases in mean annual temperatures can lead to activity earlier in the year than currently, as their growth rates increase and winter mortality can decrease. A gradual, continuing rise in atmospheric $\mathrm{CO}_{2}$ will also have an effect (Cannon 1998). Range expansion could result in increased abundance of insect species near their northern limit ranges (Cannon 1998). Ranges are already shifting: in one study, it was estimated that $59 \%$ of a total of 1,598 species has demonstrated measurable changes in their distributions and phenologies over the past 20 to 140 years (Parmesan and Yohe 2003). Increased precipitation is likely to cause a qualitative and quantitative increase in insect breeding sites, while higher temperatures will affect the density of vegetation. In turn, this will affect biotic factors such as competition, predation, parasitism, and disease (Cannon 1998). These aspects are important as arthropods and annelids may act as transport hosts, thus causing transmission of T. gondii through the environment (Wallace 1972; Ruiz et al. 1973; Ruiz and Frenkel 1980; Chinchilla et al. 1994). Flies can carry sporulated oocysts on their exoskeleton (Wallace 1971; Graczyk et al. 2001) and might cause infection of birds and mammals. Also, changes in mammal ecology may contribute to the spread of $T$. gondii throughout the environment. Rodents are also considered as reservoir hosts for T. gondii (Dubey 1995; Hejlicek et al. 1997; Kijlstra et al. 2008), next to many other pathogens (Mills and Childs 1998; Meerburg and Kijlstra 2007; Meerburg et al. 2009). According several studies, these animals play an important role in the transmission of $T$. gondii to zoo animals (Pertz et al. 1997) and swine (Kijlstra et al. 2004a, b). Although the response of rodents to climatic factors can vary considerably from species to species (Githeko et al. 2000), it seems reasonable that, because of global climate change, shelter conditions improve (more leaf coverage because of higher temperatures and more $\mathrm{CO}_{2}$ ) and food availability increases. This will probably affect litter sizes (especially more survival of rodent youngsters), which through congenital transmission may be infected with T. gondii. Thus, there will be an increased risk that they transfer the parasite to cats (as definitive host) or livestock animals (accidental hosts). In the end, this could lead to a higher prevalence of the parasite throughout the environment, resulting in more cases of human infection.

\section{Past, present, and future: concluding remarks}

Through a combination of environmental and anthropogenic factors, it is likely possible for $T$. gondii to expand its home range significantly in the future. Climatic conditions may improve the well-being of the parasite throughout the environment in some European regions (Fig. 4). Further urbanization may heighten interaction between domestic or stray cats and wild animals (Hill et al. 2008), thus affecting the presence of $T$. gondii in the environment. Changing farming systems may result in more interaction between wild fauna and livestock. During the past century, we have seen many changes in $T$. gondii prevalence, mainly because of 
anthropogenic factors. Until the late 1960s, pigs in NorthWestern Europe were kept mainly outdoors and in direct contact with the surrounding environment. Because of this farming system, $75 \%$ of animals were shown to be infected with the parasite (Tenter et al. 2000). However, in the 1970s, agriculture became more and more industrialized and pigs had no outdoor access. This had significant effects: in the UK, the seroprevalence in humans in different age groups was determined between 1969 and 1990 (Walker et al. 1992). A prevalence of $40-50 \%$ was attained by the age class 41-45 years. In 1990, this level was not approached until the 66-70-year class. Thus, the exposure to T. gondii declined in this study over a 20-year period (Walker et al. 1992). Also, in Sweden, a declining incidence was reported in a study that followed longitudinal seroprevalence in pregnant women during a 40-50-year period (Nokes et al. 1993). During the last two decades, however, a shift in the decreasing incidence is visible. Farming systems have changed drastically because of societal demands in terms of animal welfare and food animals are sometimes allowed outdoors again. However, there are also constraints as these systems may impose an increased risk of contracting the parasite (Kijlstra et al. 2004a; b).

As a result of the expansion of T. gondii in NorthWestern Europe, it is likely that more people will come into contact with this parasite, one way or another. As a consequence and in order to counter the severe consequences, more attention should be paid to the development of human vaccines which offer full protection to the parasite (Bout et al. 2002; Bhopale 2003; Dubey 2008; Rosenberg et al. 2009). Until these are developed, treatment optimization and other means of prevention (e.g., freezing of meat (Kijlstra and Jongert 2009) or consumer education) should be emphasized.

Acknowledgements The authors would like to thank the anonymous referees for their efforts.

Open Access This article is distributed under the terms of the Creative Commons Attribution Noncommercial License which permits any noncommercial use, distribution, and reproduction in any medium, provided the original author(s) and source are credited.

\section{References}

Afonso E, Thulliez P, Gilot-Fromont E (2006) Transmission of Toxoplasma gondii in an urban population of domestic cats (Felis catus). Int J Parasitol 36(13):1373-1382

Anonymous (2002) Climate change scenarios for the United Kingdom. Department for Environment, Food and Rural Affairs (DEFRA), London, $\mathrm{p} 7$

Aramini JJ, Stephen C, Dubey JP, Engelstoft C, Schwantje H, Ribble CS (1999) Potential contamination of drinking water with Toxoplasma gondii oocysts. Epidemiol Infect 122(2):305-315

Bahia-Oliveira LMG, Jones JL, Azevedo-Silva J, Alves CCF, Oréfice F, Addiss DG (2003) Highly endemic, waterborne toxoplasmosis in North Rio de Janeiro State, Brazil. Emerg Infect Dis 9(1):55-62
Benenson MW, Takafuji ET, Lemon SM (1982) Oocyst-transmitted toxoplasmosis associated with ingestion of contaminated water. N Engl J Med 307(11):666-669

Bhopale GM (2003) Development of a vaccine for toxoplasmosis: current status. Microbes Infect 5(5):457-462

Bosch-Driessen LE, Berendschot TT, Ongkosuwito JV, Rothova A (2002) Ocular toxoplasmosis: clinical features and prognosis of 154 patients. Ophthalmology 109:869-878

Bout DT, Mevelec MN, Velge-Roussel F, Dimier-Poisson I, Lebrun M (2002) Prospects for a human toxoplasma vaccine. Curr Drug Targets Immune Endocr Metabol Disord 2(3):227-234

Bowie WR, King AS, Werker DH, Isaac-Renton JL, Bell A, Eng SB, Marion SA (1997) Outbreak of toxoplasmosis associated with municipal drinking water. Lancet 350(9072):173-177

Cannon RJC (1998) The implications of predicted climate change for insect pests in the UK, with emphasis on non-indigenous species. Glob Chang Biol 4(7):785-796

Chinchilla M, Guerrero OM, Castro A, Sabah J (1994) Cockroaches as transport hosts of the protozoan Toxoplasma gondii. Rev Biol Trop 42(1-2):329-331

Cook AJC, Gilbert RE, Buffolano W, Zufferey J, Petersen E, Jenum PA, Foulon W, Semprini AE, Dunn DT, Holliman R (2000) Sources of toxoplasma infection in pregnant women: European multicentre case-control study commentary: congenital toxoplasmosisfurther thought for food. BMJ 321(7254):142-147

Dubey JP (1995) Duration of immunity to shedding of Toxoplasma gondii oocysts by cats. J Parasitol 81(3):410-415

Dubey JP (1998) Toxoplasma gondii oocyst survival under defined temperatures. J Parasitol 84(4):862-865

Dubey JP (2008) The history of Toxoplasma gondii: the first 100 years. J Eukaryot Microbiol 55(6):467-475

Dubey JP, Beattie CP (1988) Toxoplasmosis of animals and man. CRC, Boca Raton, p 40

Dubey JP, Jones JL (2008) Toxoplasma gondii infection in humans and animals in the United States. Int J Parasitol 38(11):1257-1278

Dubey JP, Miller NL, Frenkel JK (1970) The Toxoplasma gondii oocyst from cat feces. J Exp Med 132(4):636-662

Dubey JP, Thulliez P, Powell EC (1995) Toxoplasma gondii in Iowa sows: comparison of antibody titers to isolation of $T$. gondii by bioassays in mice and cats. J Parasitol 81(1):48-53

Frenkel JK, Ruiz A, Chinchilla M (1975) Soil survival of Toxoplasma oocysts in Kansas and Costa Rica. Am J Trop Med Hyg 24 (3):439-443

Githeko AK, Lindsay SW, Confalonieri UE, Patz JA (2000) Climate change and vector-borne diseases: a regional analysis. Bull World Health Organ 78(9):1136-1147

Graczyk TK, Knight R, Gilman RH, Cranfield MR (2001) The role of non-biting flies in the epidemiology of human infectious diseases. Microbes Infect 3(3):231-235

Havelaar AH, Kemmeren JM, Kortbeek LM (2007) Food safety: disease burden of congenital toxoplasmosis. Clin Infect Dis 44 (11): 1467-1474

Hejlicek K, Literak I, Nezval J (1997) Toxoplasmosis in wild mammals from the Czech Republic. J Wildl Dis 33(3):480-485

Hill NJ, Dubey JP, Vogelnest L, Power ML, Deane EM (2008) Do free-ranging common brushtail possums (Trichosurus vulpecula) play a role in the transmission of Toxoplasma gondii within a zoo environment? Vet Parasitol 152(3-4):202-209

Houghton JT, Ding Y, Griggs DJ, Noguer M, Van der Linden PJ, Dai X, Maskell K, Johnson CA (2001) Climate change 2001: the scientific basis. Cambridge University Press, Cambridge, p 84

Kapperud G, Jenum PA, Stray-Pedersen B, Melby KK, Eskild A, Eng J (1997) Risk factors for Toxoplasma gondii infection in pregnancy: results of a prospective case-control study in Norway. Obstet Gynecol Surv 52(3):158-159 
Kijlstra A, Jongert E (2008) Control of the risk of human toxoplasmosis transmitted by meat. Int J Parasitol 38(12):1359-1370

Kijlstra A, Jongert E (2009) Toxoplasma-safe meat: close to reality? Trends Parasitol 25(1):18-22

Kijlstra A, Eissen OA, Cornelissen J, Munniksma K, Eijck I, Kortbeek $\mathrm{T}$ (2004a) Toxoplasma gondii infection in animal-friendly pig production systems. Invest Ophthalmol Vis Sci 45(9):3165-3169

Kijlstra A, Meerburg BG, Mul MF (2004b) Animal-friendly production systems may cause re-emergence of Toxoplasma gondii. NJAS - Wageningen J Life Sci 52(2):119-128

Kijlstra A, Meerburg B, Cornelissen J, De Craeye S, Vereijken P, Jongert E (2008) The role of rodents and shrews in the transmission of Toxoplasma gondii to pigs. Vet Parasitol 156(3-4):183-190

Lindsay DS, Blagburn BL, Dubey JP (2002) Survival of nonsporulated Toxoplasma gondii oocysts under refrigerator conditions. Vet Parasitol 103(4):309-313

Mead PS, Slutsker L, Dietz V, McCaig LF, Bresee JS, Shapiro C, Griffin PM, Tauxe RV (1999) Food-related illness and death in the United States. Emerg Infect Dis 5(5):607-625

Meerburg BG, Kijlstra A (2007) Role of rodents in transmission of Salmonella and Campylobacter. J Sci Food Agric 87:27742781

Meerburg BG, Riel JWV, Cornelissen JB, Kijlstra A, Mul MF (2006) Cats and goat whey associated with Toxoplasma gondii infection in pigs. Vector Borne Zoonotic Dis 6(3):266-274

Meerburg BG, Singleton GR, Kijlstra A (2009) Rodent-borne diseases and their risks for public health. Crit Rev Microbiol (in press)

Miller MA, Gardner IA, Kreuder C, Paradies DM, Worcester KR, Jessup DA, Dodd E, Harris MD, Ames JA, Packham AE, Conrad PA (2002) Coastal freshwater runoff is a risk factor for Toxoplasma gondii infection of southern sea otters (Enhydra lutris nereis). Int J Parasitol 32(8):997-1006

Mills JN, Childs JE (1998) Ecologic studies of rodent reservoirs: their relevance for human health. Emerg Infect Dis 4:529-537

Montoya JG, Liesenfeld O (2004) Toxoplasmosis. Lancet 363 (9425):1965-1976

Nokes DJ, Forsgren M, Gille E, Ljungström I (1993) Modelling toxoplasma incidence from longitudinal seroprevalence in Stockholm, Sweden. Parasitology 107(Pt1):33-40

Parmesan C, Yohe G (2003) A globally coherent fingerprint of climate change impacts across natural systems. Nature 421(6918):37-42

Patz JA, Graczyk TK, Geller N, Vittor AY (2000) Effects of environmental change on emerging parasitic diseases. Int $\mathrm{J}$ Parasitol 30(12-13):1395-1405
Pertz C, Dubielzig RR, Lindsay DS (1997) Fatal Toxoplasma gondii infection in golden lion tamarins (Leontopithecus rosalia rosalia). J Zoo Wild Med 28(4):491-493

Rosenberg C, De Craeye S, Jongert E, Gargano N, Beghetto E, Del Porto P, Vorup-Jensen T, Petersen E (2009) Induction of partial protection against infection with Toxoplasma gondii genotype II by DNA vaccination with recombinant chimeric tachyzoite antigens. Vaccine 27(18):2489-2498

Ruiz A, Frenkel JK (1980) Intermediate and transport hosts of Toxoplasma gondii in Costa Rica. Am J Trop Med Hyg 29(6):1161-1166

Ruiz A, Frenkel JK, Cerdas L (1973) Isolation of toxoplasma from soil. J Parasitol 59(1):204-206

Ruosteenoja K, Carter TR, Jylhä K, Tuomenvirta H (2003) Future climate in world regions: an intercomparison of model-based projections for the new IPCC emissions scenarios. Finnish Environment Institute, Helsinki, p 81

Sroka J, Wójcik-Fatla A, Dutkiewicz J (2006) Occurrence of Toxoplasma gondii in water from wells located on farms. Ann Agric Environ Med 13:169-175

Tenter AM, Heckeroth AR, Weiss LM (2000) Toxoplasma gondii: from animals to humans. Int J Parasitol 30(12-13):1217-1258

Thomas CD, Cameron A, Green RE, Bakkenes M, Beaumont LJ, Collingham YC, Erasmus BFN, de Siqueira MF, Grainger A, Hannah L, Hughes L, Huntley B, van Jaarsveld AS, Midgley GF, Miles L, Ortega-Huerta MA, Townsend Peterson A, Phillips OL, Williams SE (2004) Extinction risk from climate change. Nature 427(6970):145-148

Van den Hurk B, Klein Tank A, Lenderink G, Van Ulden A, Van Oldenborgh GJ, Katsman C, Van den Brink H, Bessembinder J, Hazeleger W, Drijfhout S (2006) KNMI Climate Change Scenarios 2006 for the Netherlands. KNMI Scientific Report WR 2006-01, KNMI, De Bilt

Vollaire MR, Radecki SV, Lappin MR (2005) Seroprevalence of Toxoplasma gondii antibodies in clinically ill cats in the United States. Am J Vet Res 66(5):874-877

Walker J, Nokes DJ, Jennings R (1992) Longitudinal study of Toxoplasma seroprevalence in South Yorkshire. Epidemiol Infect 108(1):99-106

Wallace G (1971) Experimental transmission of Toxoplasma gondii by filth-flies. Am J Trop Med Hyg 20(3):411-413

Wallace GD (1972) Experimental transmission of Toxoplasma gondii by cockroaches. J Infect Dis 126(5):545-547

Wallon M, Kodjikian L, Binquet C, Garweg J, Fleury J, Quantin C, Peyron F (2004) Long-term ocular prognosis in 327 children with congenital toxoplasmosis. Pediatrics 113(6):1567-1572 